\title{
Analysis of Human Interaction in Green Open Spaces: A case study in Shah Alam, Malaysia
}

\author{
Filzani Illia Ibrahim¹, Dasimah Omar², Nik Hanita Nik Mohamad³ \\ 1School of Architecture Building and Design, Faculty of Innovation and Technology, \\ Taylor's University, Malaysia \\ ${ }^{2}$ Centre of Studies for Town and Regional Planning \\ ${ }^{3}$ Centre of Studies for Landscape Architecture \\ Faculty of Architecture, Planning and Surveying, \\ Universiti Teknologi MARA, Malaysia
}

filzanillia@gmail.com; dasimaho@yahoo.com; nhanita62@yahoo.com

\begin{abstract}
Currently, urban open spaces are emerging as one of the most critical areas in the urban fabric. This paper has been produced to study multi-dimensional human interaction towards open spaces given a sustainable city.

Keywords: open spaces; sustainability; human interaction; landscape

eISSN 2398-4295 @ 2019. The Authors. Published for AMER ABRA cE-Bs by e-International Publishing House, Ltd., UK. This is an open-access article under the CC BY-NC-ND license (http://creativecommons.org/licenses/bync-nd/4.0/). Peer-review under responsibility of AMER (Association of Malaysian Environment-Behaviour Researchers), ABRA (Association of Behavioural Researchers on Asians) and CE-Bs (Centre for EnvironmentBehaviour Studies), Faculty of Architecture, Planning \& Surveying, Universiti Teknologi MARA, Malaysia.

DOI: http://dx.doi.org/10.21834/ajbes.v4i16.175
\end{abstract}




\subsection{Introduction}

There is a different theory that relate to the multi-dimensional human interaction in the open spaces. Arifin (2005) stated that open areas with plant represent natural contact with human as it acts as production for oxygen, controlling the surrounding system and also the soil water. Moreover, the natural landscape in open spaces can sometimes play a key role in promoting social interaction (Oguz, 2000).

Hence, as there are various studies on how open spaces provide positive reaction to human and nature, this paper aims to prove that the multi-dimensional social interaction in a different hierarchy of open spaces offers positive impacts to the urban dwellers. The major theme of multi-dimensional human interaction in public areas is human-human interaction and human-nature interaction. Under the human-human interaction, three variables can be measured which are social interaction, citizen participation and sense of community. As for the human-nature interaction, the variables to be measured are contacted with nature, aesthetic preference, and recreational or play.

\subsection{Literature Review}

Sustainable development can be defined as development that survives as the least contentious, probably because it lacks precise detail, and so is open to interpretations that allow different stakeholders to feel comfortable (Tweed \& Sutherland, 2007). Whereas sustainable city can be defined as a city that is able to provide the basic needs of city inhabitants such as infrastructure, civic amenities, health and medical care, housing, education, transportation, employment, good governance and ensure the populations needs are met benefiting all sectors of society (Shamsuddin \& Azmizam, 2013). Hence, sustainable and urban planning is vital for the establishment of a further urban envisioning where it is a crucial element for the creation of sustainable cities (Rosales, 2010). Leaders at the regional and municipals levels are faced with the challenge of balancing the broader technical demands of sustainability and the specific practical applications of citizens.

\subsection{Open Spaces}

As for open spaces, it can be defined as an area where it has specific functions and intention which is usually for recreational activities. Open space is typically bounded by the element of natural either in full or semi-bounded way whereby recreation is an activity done by people without any force of anyone (voluntarily) which then aim for self-satisfaction and done during their own free time (Shuib, 2008). Examples of recreational activities are cycling, jogging and playing badminton. The primary function of the open space is to satisfy people's recreational need. It represents a vital role in improving the environmental system (Marzukhi et al., 2012). Apart from that, Arifin (2005) claimed that open space with its plant represents as a green open space which acts as production for the oxygen, controlling the surrounding ecosystem and controlling the soil water. Other than that open spaces also take the role as a buffer towards sounds, wind, dust and the sun. But the truth is the designer will plan the open spaces based on real or perceived notions of recreation needs. Moreover, open spaces help in reducing stress, rejuvenate city dwellers and provide a sense of tranquillity (Kaplan, 1993). 
Conway (2000) verifies beliefs about stress reduction benefits and mental health through the experience of the use of open spaces.

Hence, Matsuoka \& Kaplan, (2008), provide valuable insight into how human interact with outdoor urban environments, which included open spaces itself. They offer significant themes that are directly linked with the public areas which are; human-nature interaction and humanhuman interaction.

Table 1: Theoretical Framework of Human Interaction in Open Spaces

\begin{tabular}{|c|c|c|c|c|c|c|c|}
\hline \multirow[t]{2}{*}{ Author } & \multicolumn{3}{|c|}{ Nature needs } & \multicolumn{3}{|c|}{ Human needs } & \multirow{2}{*}{$\begin{array}{c}\text { Primary Data } \\
\text { Quantitative/ } \\
\text { Qualitative } \\
\text { Data }\end{array}$} \\
\hline & $\begin{array}{c}\text { Contact } \\
\text { with } \\
\text { nature }\end{array}$ & $\begin{array}{c}\text { Aesthetic } \\
\text { Preference }\end{array}$ & $\begin{array}{l}\text { Recreation/ } \\
\text { play }\end{array}$ & $\begin{array}{c}\text { Social } \\
\text { interaction/ } \\
\text { privacy }\end{array}$ & $\begin{array}{c}\text { Citizen } \\
\text { Participation }\end{array}$ & $\begin{array}{c}\text { Sense of } \\
\text { Community }\end{array}$ & \\
\hline Austin (2004) & $\bullet$ & & & $\bullet$ & & $\bullet$ & Qualitative \\
\hline $\begin{array}{l}\text { Chiesura } \\
(2004)\end{array}$ & $\bullet$ & & $\bullet$ & $\bullet$ & $\bullet$ & & Quantitative \\
\hline $\begin{array}{l}\text { Gobster } \\
(2001)\end{array}$ & $\bullet$ & - & $\bullet$ & & - & - & Both \\
\hline Oguz (2000) & $\bullet$ & $\bullet$ & $\bullet$ & $\bullet$ & & & Qualitative \\
\hline $\begin{array}{l}\text { Ozguner and } \\
\text { Kendle } \\
(2006) \\
\end{array}$ & - & - & & - & & & Quantitative \\
\hline $\begin{array}{l}\text { Abu- } \\
\text { Ghazzeh } \\
\text { (1996) } \\
\end{array}$ & - & & & & - & - & Qualitative \\
\hline $\begin{array}{l}\text { Crow et.al } \\
(2006)\end{array}$ & $\bullet$ & $\bullet$ & $\bullet$ & $\bullet$ & & & Quantitative \\
\hline $\begin{array}{l}\text { Dokmeci and } \\
\text { Berkoz } \\
(2000)\end{array}$ & - & - & & - & & & Quantitative \\
\hline $\begin{array}{l}\text { Hull et.al } \\
\text { (1994) }\end{array}$ & - & & & & & - & Qualitative \\
\hline $\begin{array}{l}\text { Lucy and } \\
\text { Phillips } \\
\text { (1997) }\end{array}$ & - & & & & & - & Qualitative \\
\hline $\begin{array}{l}\text { Vogt and } \\
\text { Marans } \\
(2004)\end{array}$ & - & - & - & - & & & Qualitative \\
\hline $\begin{array}{l}\text { Herrington } \\
\text { and } \\
\text { Studtman } \\
\text { (1998) }\end{array}$ & $\bullet$ & & & - & & & Qualitative \\
\hline $\begin{array}{l}\text { Coles and } \\
\text { Bussey } \\
(2000) \\
\end{array}$ & - & & & - & - & & Both \\
\hline $\begin{array}{l}\text { Simson } \\
(2000)\end{array}$ & $\bullet$ & - & & & & - & Qualitative \\
\hline $\begin{array}{l}\text { Yuen and } \\
\text { Hien (2005) }\end{array}$ & $\bullet$ & $\bullet$ & - & - & & & Qualitative \\
\hline
\end{tabular}




\subsection{Typologies of Open Spaces}

As open spaces create many benefits and opportunities towards social, health, environmental and economical, thus it shows that open spaces act as a vital element towards daily urban life (Woolley, 2003). Therefore, the question that arises is what typologies of public areas that are important? Different types of urban open spaces can be used at various stages of a person's journey through life which comprises of childhood, adolescence, early and late adult. Moreover, different typologies of open spaces might offer various activities, design and accessibilities. Woolley (2003) defined two basic types of open spaces as green spaces and civic spaces. The first category of green spaces is then further divided into parks and garden, provision for children and teenagers, amenity green space, outdoor space facilities, allotments, community gardens and urban farms, and natural and semi-natural urban green spaces-including woodland and urban forestry and green areas.

Hence, these typologies help to describe indirectly towards the quality of space itself. Apart from that, it also takes into consideration the experience of the area for the user or the value that an individual might give to a particular area. Thus, these typologies are enhanced and determined from the various point of view of the planner, designer or manager. It is basically to help priorities urban open spaces for development or regeneration. Mertes (1996) claimed that these public spaces typologies are intended to be used as guidelines at the local level. The revised classifications for parks, recreation areas, and open spaces expand upon past classifications to take into consideration local community needs. Thus, a typology has been suggested form the user's point of view which consists of three groupings of open spaces which are domestic, neighbourhood and civic (Woolley, 2003). These three groupings are based upon the concept of home range.

In the context of Malaysia, it has made tremendous progress in the development of open spaces in the last five decades since its formal introduction as part of the urban fabric (Department of Town and Country Planning Peninsular Malaysia, 2005). During the colonial era, open spaces were the exclusive domain of the rich and the influential. As with improved living standards, a greater appreciation toward open spaces has evolved for better recognition and pleasant environment, natural living, and a balanced ecology (Department of Town and Country Planning Peninsular Malaysia, 2005). As time has evolved, and the function of open spaces might differ from time to time, it can be seen that there are several types of public areas designed in Malaysia. Thus, according to the Department of Town and Country Planning Peninsular Malaysia (2005), there are seven types of open spaces typologies that area applied in Malaysia. The types of public spaces are characterised by the population, size of the open spaces and the facilities provided for each of the open spaces. It is vital to understand the hierarchy of open spaces for a better understanding of the research area. This is due to the different typology of open spaces might offer different needs and purposes for the urban dwellers in using the open spaces. Hence, Table 2.1 below shows the hierarchy of open spaces according to the Department of Town and Country Planning Peninsular Malaysia (2013). 
Table 2.3: Hierarchy and Functions of Open Spaces

\begin{tabular}{|c|c|c|c|c|}
\hline Hierarchy & $\begin{array}{l}\text { Size } \\
\text { (Hectares) }\end{array}$ & $\begin{array}{l}\text { Service } \\
\text { Distances }\end{array}$ & Population Size & Function \\
\hline National Park & No Limit & No limit & Whole Country & $\begin{array}{l}\text { Open spaces that have the } \\
\text { function for research, nature } \\
\text { conservation and national } \\
\text { heritage. }\end{array}$ \\
\hline Metropolitan Park & 100.0 & No limit & Whole Region & $\begin{array}{l}\text { Open spaces that function as } \\
\text { local attraction for } \\
\text { recreational activities and } \\
\text { nature appreciation }\end{array}$ \\
\hline Urban Park & 40.0 & Within $5 \mathrm{~km}$ & $>50,000$ & $\begin{array}{l}\text { Open spaces that function as } \\
\text { local attraction for } \\
\text { recreational activities and } \\
\text { nature appreciation }\end{array}$ \\
\hline Local Park & 8.0 & Within 3km & $12,000-50,000$ & $\begin{array}{l}\text { Open spaces that cater for } \\
\text { local dwellers for recreational } \\
\text { purposes, sport and social } \\
\text { community. }\end{array}$ \\
\hline $\begin{array}{l}\text { Neighbourhood } \\
\text { Park }\end{array}$ & 2.0 & $\begin{array}{l}\text { Within } \\
1.5 \mathrm{~km}\end{array}$ & $3,000-12,000$ & $\begin{array}{l}\text { Open spaces that cater for } \\
\text { local dwellers for recreational } \\
\text { purposes, sport and social } \\
\text { community. }\end{array}$ \\
\hline Playfield & 0.6 & Within $1 \mathrm{~km}$ & $1,000-3,000$ & $\begin{array}{l}\text { Open spaces that cater for } 3 \\
\text { division of neighbourhood } \\
\text { which functions as } \\
\text { recreational activities for } \\
\text { children, teenagers and } \\
\text { adults. }\end{array}$ \\
\hline Playground & 0.2 & Within $1 \mathrm{~km}$ & $300-1,000$ & $\begin{array}{l}\text { Active open spaces in } \\
\text { suburban areas for primary } \\
\text { school children. }\end{array}$ \\
\hline Play lot & 0.1 & $\begin{array}{l}\text { Within } \\
0.5 \mathrm{~km}\end{array}$ & $<300$ & $\begin{array}{l}\text { Small passive recreational } \\
\text { areas for children and citizen } \\
\text { social interaction. }\end{array}$ \\
\hline
\end{tabular}

Source: JPBD (2013), Garis Panduan Perancangan Tanah Lapang dan Kawasan Rekreasi.

\subsection{Human Interaction Theory}

According to Blumer and Shibutani (1973), in general, there are two levels of human interaction. The first one is symbolic interaction, which is uniquely human and second, nonsymbolic communication, which is shared with infrahuman. Blumer and Shibutani (1973:14) stated that "conception of social interaction is a highly cognitive, non-affective phenomenon.

The primary reason for human interaction according to Dewey (2005), which is associated with moral conduct was the active connectedness of human beings with one another, which is characterised by their "mutual intertwined activities" such as desire, beliefs, judgement, satisfaction and dissatisfaction. 
Human interaction then is influenced by individual need towards the environment and how the perceived benefits might affect negatively or positively are based on the selfjudgement. Thus, it is vital to know about society and people needs and preferences. Maslow (1954) provides an excellent example for the identification of the basic needs and create a foundation. Figure 1 below shows the Maslow hierarchy of needs of human interaction.

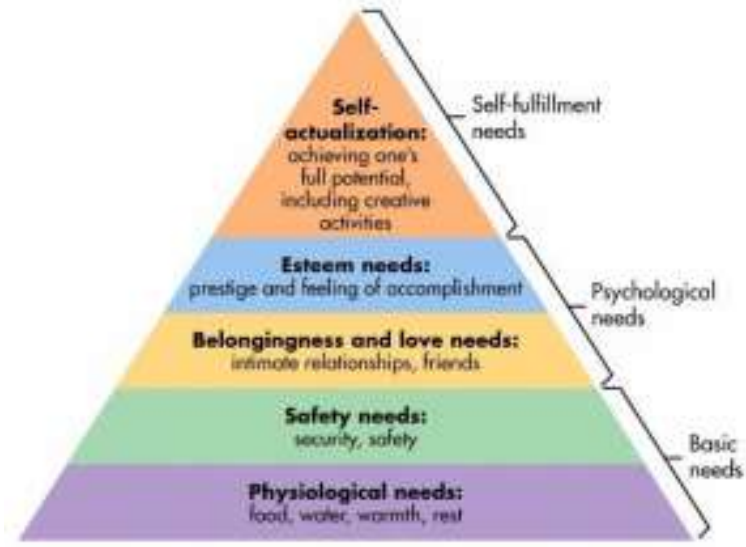

Figure 1: Maslow Hierarchy of Human Interaction Needs Source: Maslow (1943)

Maslow (1943) stated that people are motivated to achieve individual needs and that some needs take precedence over others. The most basic requirement is for physical survival, and this will be the first thing that motivates the behaviour. Once that level is fulfilled the next level up is what drives, and so on.

According to the model, the five-stage model can be divided into deficiency needs and growth needs. The first four levels are often referred to as deficiency needs (D-needs), and the top level is known as growth or being needs (B-needs). The deficiency needs are said to motivate people when they are unmet. Also, the obligation to fulfil such commitments will become stronger the longer the duration they are denied.

Hence, one must satisfy lower level deficit needs before progressing on to meet higher level growth needs. When a deficit need has been filled it will go away. Human activities become habitually directed towards achieving the next set of requirements that human has yet to satisfy. These then become salient human needs. However, growth needs continue to be felt and may even become stronger once they have been engaged. Once these growth needs have been reasonably satisfied, one may be able to reach the highest level called selfactualisation.

Every person is capable and has the desire to move up the hierarchy toward a level of self-actualisation. Unfortunately, progress is often disrupted by a failure to meet lower level needs. Life experiences may cause an individual to fluctuate between levels of the hierarchy. Therefore, not everyone will move through the authority in a uni-directional manner but may move back and forth between the different types of needs. 


\subsection{Methodology}

This research applied multiple case study method as a research approach allowing an indepth study on the research topic by focusing on the relationship and process within a social setting that is interrelated among each other (Sekaran, 2013). Unlike most scientific experiments which the parameters are artificially built, case studies are carried out in a natural setting. In this research, the multiple case study methods are applied to support the data of the research domain namely the human-human interaction in open spaces (D2) and human-nature interaction in public areas (D3).

The questionnaire was convenience distributed to the users of open spaces at the selected case studies area during morning and evening hour in both weekend and weekdays to ensure hundred per cent $(100 \%)$ response rate. The survey was distributed at all five study areas with the help of five (5) research assistants that has been assigned for the research. The samples of each study areas were taken using simple random sampling. The response rate for this questionnaire survey is 100 per cent.

\subsection{Results and Findings}

The data from the survey questionnaires coded into SPSS software for statistical analysis. The main focused this analysis is to understand the relationship of human interactions that took place in the open spaces area.

\subsection{Result and Findings on Human-Nature Interaction}

Hence, from the exploratory survey conducted suggest that the human-nature interaction in open spaces domain can be divided into three which are in contact with nature, aesthetic preference, recreation and play. For Contact with Nature domains, Neighbourhood Park shows the highest significant numbers in terms of design, natural appearance, sense of calmness, activities provided an understanding of nature appreciation. In comparison, the playground also shows a significant number of physical presence and taste of peace. As for the other types of open spaces, none shows considerable value in the public areas about contact with nature. However contact with quality could promoting stress reduction, relaxation and restoration rely to a large extent upon the provision of open space (Green Space Scotland, 2008). Moreover, Ulrich et al. (1991) report that natural settings restore positive effects and reduce fear, anger and aggression based on the attention restoration theory and stress reduction theory. Hence, contact with nature interaction should be considered in the design stages of open spaces. In this study, the design of these typologies of public areas should be improved and relate to the contact with nature domain as it promotes not only physical but also mental wellbeing. In comparison with aesthetic preference domain, Local Park shows the highest number of significant values in terms of natural appearances, a sense of calmness, a sense of appreciation and overall satisfaction. However, Neighbourhood Park also shows a considerable amount on an understanding of gratitude towards aesthetic preference domain in the open spaces. Hence, aesthetical preference could be improved in all of the typological of public areas as stated by Jim and Chen (2006) as aesthetic choice 
can be seen as a range of topics related to the bases for preference, including several issues such as scenic beauty, the degree of cleanliness, and pleasant sounds.

Table 3: Overall Findings on Human-Nature Interaction in Open Spaces

\begin{tabular}{|c|c|c|c|c|c|c|}
\hline \multicolumn{7}{|c|}{ Contact with Nature Domain } \\
\hline & & $\begin{array}{l}\text { Neighbourho } \\
\text { od park }\end{array}$ & $\begin{array}{l}\text { Playfiel } \\
\mathrm{d}\end{array}$ & $\begin{array}{l}\text { Local } \\
\text { park }\end{array}$ & $\begin{array}{l}\text { Playgro } \\
\text { und }\end{array}$ & $\begin{array}{l}\text { Urban } \\
\text { park }\end{array}$ \\
\hline $\begin{array}{ll}\text { C } \\
\text { N1 }\end{array}$ & $\begin{array}{l}\text { The design of the open spaces allows me } \\
\text { to contact with nature }\end{array}$ & 0.0000 & 0.1448 & 0.8420 & 0.0793 & 0.6119 \\
\hline $\begin{array}{ll}\mathrm{C} \\
\mathrm{N} 2\end{array}$ & $\begin{array}{l}\text { I like the natural appearance of the open } \\
\text { space }\end{array}$ & 0.0391 & 0.0664 & 0.4124 & 0.0275 & 0.9085 \\
\hline $\begin{array}{ll}\mathrm{C} \\
\mathrm{N} 3\end{array}$ & $\begin{array}{l}\text { I feel calm with the nature provided in the } \\
\text { open spaces }\end{array}$ & 0.0025 & 0.1146 & 0.6688 & 0.0000 & 0.8369 \\
\hline $\begin{array}{ll}\mathrm{C} \\
\mathrm{N} 4\end{array}$ & $\begin{array}{l}\text { I can pursue many activities with nature } \\
\text { in this open spaces }\end{array}$ & 0.0001 & 0.1413 & 0.8490 & 0.6567 & 0.0768 \\
\hline $\begin{array}{ll}\text { C } \\
\text { N5 }\end{array}$ & $\begin{array}{l}\text { I can appreciate the nature when I'm in } \\
\text { the open space }\end{array}$ & 0.0023 & 0.0782 & 0.4947 & 0.5010 & 0.1223 \\
\hline $\begin{array}{l}\mathrm{C} \\
\mathrm{N} 6\end{array}$ & $\begin{array}{l}\text { Overall, I would rate the nature in this } \\
\text { open space as very satisfying. }\end{array}$ & 0.5867 & 0.6556 & 0.6172 & 0.3070 & 0.3931 \\
\hline \multicolumn{7}{|c|}{ Aesthetic Preference Domain } \\
\hline $\begin{array}{l}\text { AP } \\
1\end{array}$ & $\begin{array}{l}\text { The open space allows me to value } \\
\text { aesthetic elements }\end{array}$ & 0.1749 & 0.9512 & 0.2187 & 0.8743 & 0.1656 \\
\hline $\begin{array}{l}\text { AP } \\
2\end{array}$ & $\begin{array}{l}\text { I like the natural preference in this open } \\
\text { space }\end{array}$ & 0.2517 & 0.9646 & 0.0426 & 0.9267 & 0.8080 \\
\hline $\begin{array}{l}\text { AP } \\
3\end{array}$ & $\begin{array}{l}\text { I feel calm with the aesthetic elements } \\
\text { provided in the open space }\end{array}$ & 0.4123 & 0.6396 & 0.0168 & 0.5228 & 0.5362 \\
\hline $\begin{array}{l}\text { AP } \\
4\end{array}$ & $\begin{array}{l}\text { I can pursue many activities in relation } \\
\text { with the aesthetic element in this open } \\
\text { space }\end{array}$ & 0.8721 & 0.8439 & 0.1468 & 0.6251 & 0.9159 \\
\hline $\begin{array}{l}\text { AP } \\
5\end{array}$ & $\begin{array}{l}\text { I can appreciate the aesthetic elements } \\
\text { when I'm in the open space }\end{array}$ & 0.0019 & 0.7161 & 0.0441 & 0.6492 & 0.0562 \\
\hline $\begin{array}{l}\text { AP } \\
6\end{array}$ & $\begin{array}{l}\text { Overall, I would rate the aesthetic } \\
\text { preference in this open space as very } \\
\text { satisfying. }\end{array}$ & 0.4010 & 0.0611 & 0.0152 & 0.5186 & 0.1717 \\
\hline \multicolumn{7}{|c|}{ Recreational and Play Domain } \\
\hline $\begin{array}{l}R \\
P\end{array}$ & $\begin{array}{l}\text { The open spaces allows me to have } \\
\text { recreational activities }\end{array}$ & 0.3629 & 0.0031 & 0.0199 & 0.4505 & 0.2513 \\
\hline $\begin{array}{l}\mathrm{R} \\
\mathrm{P} 2\end{array}$ & $\begin{array}{l}\text { The open spaces provides various } \\
\text { activities for recreational purposes }\end{array}$ & 0.6393 & 0.0079 & 0.0005 & 0.9463 & 0.4982 \\
\hline $\begin{array}{l}\mathrm{R} \\
\mathrm{P} 3\end{array}$ & $\begin{array}{l}\text { I feel calm when doing recreational } \\
\text { activities here }\end{array}$ & 0.7070 & 0.3338 & 0.0016 & 0.5816 & 0.4377 \\
\hline $\begin{array}{l}\mathrm{R} \\
\mathrm{P} 4\end{array}$ & $\begin{array}{l}\text { I can pursue many physical activities in } \\
\text { this open spaces }\end{array}$ & 0.1176 & 0.0136 & 0.0000 & 0.2005 & 0.6688 \\
\hline $\begin{array}{l}\mathrm{R} \\
\mathrm{P} 5 \\
\end{array}$ & $\begin{array}{l}\text { There are various facilities provided in the } \\
\text { open spaces for recreational activities }\end{array}$ & 0.0311 & 0.2663 & 0.0089 & 0.5784 & 0.4008 \\
\hline $\begin{array}{l}\mathrm{R} \\
\mathrm{P} 6\end{array}$ & $\begin{array}{l}\text { I normally do recreational activities here } \\
\text { alone }\end{array}$ & 0.0546 & 0.1271 & 0.0053 & 0.4970 & 0.3873 \\
\hline $\begin{array}{l}\mathrm{R} \\
\mathrm{P} 7\end{array}$ & $\begin{array}{l}\text { I normally do recreational activities here } \\
\text { with my partner/group }\end{array}$ & 0.7422 & 0.7491 & 0.0054 & 0.7715 & 0.4960 \\
\hline
\end{tabular}




\begin{tabular}{|c|c|c|c|c|c|}
\hline $\begin{array}{l}\mathrm{R} \\
\mathrm{P} 8\end{array}$ & $\begin{array}{l}\text { Overall, I would rate the recreational } \\
\text { activities provided in the open space as } \\
\text { very satisfying }\end{array}$ & 0.5120 & 0.9788 & $0.0004 \quad 0.0207$ & 0.3212 \\
\hline
\end{tabular}

Other findings by Merom et al. (2003) and Gies (2006) suggest that close access to open spaces does encourage greater use by local people that contributes to higher physical activity. About this study, all types of public areas are successfully provided interaction for the recreational activities except for Urban Park. However, about the behaviour mapping analysis, urban park shows among the significant numbers of physical activities in the area. Giles-Corti et al. (2005) argue that attractiveness, size and specific amenities are factors that determine the use of public open spaces, which could be measured to determine the association between physical activity and public space access. Hence, specific amenities could be improved in the urban park to ensure the users' satisfaction towards recreational activities at the open spaces. Table 3 shows the overall findings on human-nature interaction in public areas.

\subsection{Result and Findings on Human-human Interaction}

For this research objective, the findings from this are used to answer the research question. The research question is: "What are the types of human-human interactions do the urban dwellers get from visiting the open space?". Hence, from the exploratory survey conducted suggest that the human-human interaction in open spaces domain can be divided into three which are social interaction, citizen participation and lastly, sense of community. For the social interaction domain, playfield shows that the open spaces give a significant value of 0.0054 compared to the other public areas. Moreover, the design of the playfield also allows the majority of the users to interact with their friends socially. According to Philips (1996), a good model of open spaces should take consider the needs of the public regarding their interactions and activities. Moreover, a good design of open spaces also should comprise all range of people and link them to their own human need. In the context of the playfield, the area is the sole functions for the football activity. This is then in tandem with Morris (2003) which stated that outdoor recreational activities might enhance social interaction.

However, in terms of happiness, the users in the neighbourhood park tend to have more significant value in comparison to the other types of open spaces. Saleh (1999) stated that several studies expressed great optimism that improved social interactions can be promoted through properly designed urban areas. These improvements include interactions among and neighbourhood residents as a whole. Hence, open spaces should be created for the purpose needed. In this study, the playfield and neighbourhood park have successfully fulfilled the function and design for the users for the use of social interaction.

As for citizen participation domain, Urban Park has the most significant value in terms of strengthening the relationship among the citizen and concern of what is happening to surround the open spaces. It shows the vitality of promoting citizen participation to achieve a superior design and to foster community support for urban landscapes (Matsuoka \& Kaplan, 
2008). In comparison with the sense of community domain, Local Park shows the most significant values in terms of the design of the spaces, relationship among users and safety. Stewart et al., (2004) revealed that the presence of public or semi-public outdoor gathering places promotes community identity. In this study, it only shows that the local park is the only typology of open spaces that successfully supports community identity. Thus it is in tandem with improper designs that concentrate on community economics rather than residents' needs (Abu-Ghazzeh, 1996). Table 4 below shows the overall findings on human-human interaction in open spaces.

Table 4: Overall Findings on Human-human Interaction in Open Spaces

\begin{tabular}{|c|c|c|c|c|c|c|}
\hline \multicolumn{7}{|c|}{ Social Interaction Domain } \\
\hline & & $\begin{array}{l}\text { Neighbourhood } \\
\text { park }\end{array}$ & $\begin{array}{l}\text { Playfi } \\
\text { eld }\end{array}$ & $\begin{array}{l}\text { Local } \\
\text { park }\end{array}$ & $\begin{array}{l}\text { Playgrou } \\
\text { nd }\end{array}$ & $\begin{array}{l}\text { Urban } \\
\text { park }\end{array}$ \\
\hline $\begin{array}{l}\text { SI } \\
1\end{array}$ & $\begin{array}{l}\text { I always come here for social } \\
\text { interaction with my friends }\end{array}$ & 0.1763 & $\begin{array}{l}0.657 \\
7\end{array}$ & 0.6617 & 0.1989 & 0.2076 \\
\hline $\begin{array}{l}\text { SI } \\
2\end{array}$ & $\begin{array}{l}\text { The open space is a suitable place for } \\
\text { social interaction }\end{array}$ & 0.4501 & $\begin{array}{l}0.301 \\
2\end{array}$ & 0.6515 & 0.0899 & 0.4986 \\
\hline $\begin{array}{l}\mathrm{SI} \\
3\end{array}$ & $\begin{array}{l}\text { I can pursue many social activities in } \\
\text { this open space }\end{array}$ & 0.9208 & $\begin{array}{l}0.683 \\
9\end{array}$ & 0.6287 & 0.6912 & 0.4410 \\
\hline $\begin{array}{ll}\mathrm{SI} \\
4\end{array}$ & $\begin{array}{l}\text { I feel happy doing social interaction in } \\
\text { this open space }\end{array}$ & 0.0065 & $\begin{array}{l}0.270 \\
8\end{array}$ & 0.5198 & 0.6563 & 0.7036 \\
\hline $\begin{array}{l}\text { SI } \\
5\end{array}$ & $\begin{array}{l}\text { The design of the open space allow me } \\
\text { to have social interaction easily with } \\
\text { my friends }\end{array}$ & 0.4104 & $\begin{array}{l}0.019 \\
2\end{array}$ & 0.6784 & 0.6441 & 0.8017 \\
\hline $\begin{array}{l}\text { SI } \\
6\end{array}$ & $\begin{array}{l}\text { Overall, I would rate the open space } \\
\text { with social interaction activities as very } \\
\text { satisfying }\end{array}$ & 0.1585 & $\begin{array}{l}0.005 \\
4\end{array}$ & 0.7232 & 0.4377 & 0.6679 \\
\hline \multicolumn{7}{|c|}{ Citizen Participation Domain } \\
\hline $\begin{array}{l}\mathrm{CP} \\
1 \\
\end{array}$ & $\begin{array}{l}\text { The open space allows me to socialize } \\
\text { with other citizens }\end{array}$ & 0.5512 & $\begin{array}{l}0.133 \\
3 \\
\end{array}$ & 0.9863 & 0.2410 & 0.3157 \\
\hline $\begin{array}{l}\text { CP } \\
2\end{array}$ & $\begin{array}{l}\text { The open space is suitable for citizen } \\
\text { participation in the community }\end{array}$ & 0.7787 & $\begin{array}{l}0.926 \\
0\end{array}$ & 0.7129 & 0.3910 & 0.9153 \\
\hline $\begin{array}{l}\text { CP } \\
3\end{array}$ & $\begin{array}{l}\text { The open space strengthen the citizen } \\
\text { participation regardless of activities } \\
\text { and events held here }\end{array}$ & 0.3722 & $\begin{array}{l}0.880 \\
7\end{array}$ & 0.7789 & 0.7405 & 0.0498 \\
\hline $\begin{array}{l}\text { CP } \\
4 \\
\end{array}$ & $\begin{array}{l}\text { The citizens here concern on what is } \\
\text { happening in the open space area }\end{array}$ & 0.5657 & $\begin{array}{l}0.808 \\
5\end{array}$ & 0.9242 & 0.7693 & 0.0291 \\
\hline $\begin{array}{l}\mathrm{CP} \\
5\end{array}$ & $\begin{array}{l}\text { Overall, I would rate the citizen } \\
\text { participation in this open space as very } \\
\text { satisfying. }\end{array}$ & 0.3599 & $\begin{array}{l}0.726 \\
2\end{array}$ & 0.5009 & 0.8517 & 0.1701 \\
\hline \multicolumn{7}{|c|}{ The Sense of Community Domain } \\
\hline $\begin{array}{l}\mathrm{SC} \\
1\end{array}$ & $\begin{array}{l}\text { The open space allows me to have } \\
\text { community events }\end{array}$ & 0.5304 & $\begin{array}{l}0.259 \\
2\end{array}$ & 0.1941 & 0.7157 & 0.5899 \\
\hline $\begin{array}{l}\mathrm{SC} \\
2\end{array}$ & $\begin{array}{l}\text { The open space allows me to know the } \\
\text { surrounding citizens of the area }\end{array}$ & 0.5030 & $\begin{array}{l}0.284 \\
0\end{array}$ & 0.0043 & 0.2746 & 0.8914 \\
\hline $\begin{array}{l}\mathrm{SC} \\
3\end{array}$ & $\begin{array}{l}\text { The open space strengthen the } \\
\text { relationship between the citizens here }\end{array}$ & 0.0001 & $\begin{array}{l}0.140 \\
7 \\
\end{array}$ & 0.0026 & 0.2893 & 0.6336 \\
\hline $\begin{array}{l}\text { SC } \\
4\end{array}$ & I feel safe while using the open space & 0.7244 & $\begin{array}{l}0.461 \\
5 \\
\end{array}$ & 0.0463 & 0.6015 & 0.6488 \\
\hline
\end{tabular}


Ibrahim, F.I., et.al. / Asian Journal of Behavioural Studies (AjBeS), 4(16) May / Aug 2019 (pp.18-32)

\begin{tabular}{|c|c|c|c|c|c|c|}
\hline $\begin{array}{l}\mathrm{SC} \\
5\end{array}$ & $\begin{array}{l}\text { I know well other people who are using } \\
\text { the open space }\end{array}$ & 0.6276 & $\begin{array}{l}0.127 \\
9\end{array}$ & 0.1622 & 0.0016 & 0.6744 \\
\hline $\begin{array}{l}\mathrm{SC} \\
6\end{array}$ & $\begin{array}{l}\text { The community here know and fully } \\
\text { utilized the open space }\end{array}$ & 0.3480 & $\begin{array}{l}0.135 \\
9\end{array}$ & 0.0979 & 0.1795 & 0.9285 \\
\hline $\begin{array}{l}\mathrm{SC} \\
7\end{array}$ & $\begin{array}{l}\text { Overall, I would rate the sense of } \\
\text { community in relation to open space } \\
\text { here as very satisfying. }\end{array}$ & 0.2113 & $\begin{array}{l}0.828 \\
5\end{array}$ & 0.0565 & 0.2893 & 0.9424 \\
\hline
\end{tabular}

Note:

Items of significant difference on dependance variable $=p$-value equal or less than 0.05

Items of no significant difference on dependance variable $=p$-value above 0.05

\subsection{Discussion}

Hence, from the exploratory survey and regression analysis conducted suggests that the proposed model is based on the overall result of the human-nature interaction and humanhuman interaction.

Table 5: Overall Findings of Perceived Benefits and Vitality of Open Spaces Domain

\begin{tabular}{|c|c|c|c|c|c|c|c|c|c|}
\hline \multirow{2}{*}{\multicolumn{2}{|c|}{ Model }} & \multicolumn{2}{|c|}{$\begin{array}{l}\text { Unstandardized } \\
\text { Coefficients }\end{array}$} & \multirow{2}{*}{$\begin{array}{l}\text { Standardize } \\
\text { d } \\
\text { Coefficients } \\
\text { Beta }\end{array}$} & \multirow[t]{2}{*}{ Sig } & \multicolumn{3}{|c|}{$\begin{array}{l}\text { Dependent Variable: Perceived } \\
\text { Benefit }\end{array}$} & \multirow{2}{*}{$\begin{array}{l}\text { Overal } \\
\text { I } \\
\text { Result }\end{array}$} \\
\hline & & $\mathrm{B}$ & $\begin{array}{l}\text { Std. } \\
\text { Error }\end{array}$ & & & $\begin{array}{l}\mathrm{R}- \\
\text { square }\end{array}$ & F-statistics & $p$-value & \\
\hline \multicolumn{10}{|c|}{ Section 18} \\
\hline \multirow[t]{3}{*}{1} & (Constant) & 2.685 & .334 & & $\begin{array}{l}.00 \\
0\end{array}$ & 0.059 & 4.004 & 0.021 & \\
\hline & Human-nature & .148 & .075 & .172 & $\begin{array}{l}.05 \\
1\end{array}$ & & & & $X$ \\
\hline & Human-human & .106 & .065 & .142 & $\begin{array}{l}.10 \\
8\end{array}$ & & & & $X$ \\
\hline \multicolumn{10}{|c|}{ Section 8} \\
\hline \multirow[t]{3}{*}{1} & (Constant) & 2.162 & .426 & & $\begin{array}{l}.00 \\
0\end{array}$ & 0.18 & 10.444 & 0 & \\
\hline & Human-nature & .044 & .091 & .045 & $\begin{array}{l}.63 \\
4\end{array}$ & & & & $X$ \\
\hline & Human-human & .360 & .083 & .412 & $\begin{array}{l}.00 \\
0\end{array}$ & & & & $\sqrt{ }$ \\
\hline \multicolumn{10}{|c|}{ Section 7} \\
\hline \multirow[t]{3}{*}{1} & (Constant) & 1.572 & .467 & & $\begin{array}{l}.00 \\
1\end{array}$ & 0.206 & 15.685 & 0 & \\
\hline & Human-nature & .064 & .129 & .049 & $\begin{array}{l}.61 \\
9\end{array}$ & & & & $X$ \\
\hline & Human-human & .558 & .130 & .424 & $\begin{array}{l}.00 \\
0\end{array}$ & & & & $\sqrt{ }$ \\
\hline \multicolumn{10}{|c|}{ Section 4} \\
\hline \multirow[t]{3}{*}{1} & (Constant) & 3.240 & .473 & & $\begin{array}{l}.00 \\
0\end{array}$ & 0.04 & 0.927 & 0.403 & \\
\hline & Human-nature & .105 & .105 & .159 & $\begin{array}{l}.32 \\
1\end{array}$ & & & & $X$ \\
\hline & Human-human & .054 & .117 & .073 & $\begin{array}{l}.65 \\
0\end{array}$ & & & & $\mathrm{X}$ \\
\hline
\end{tabular}




\begin{tabular}{|c|c|c|c|c|c|c|c|c|c|}
\hline \multicolumn{10}{|c|}{ Section 2} \\
\hline 1 & (Constant) & 1.262 & .221 & & $\begin{array}{l}.00 \\
0\end{array}$ & 0.301 & 56.474 & 0.000 & \\
\hline & Human-nature & .418 & .065 & .383 & $\begin{array}{l}.00 \\
0\end{array}$ & & & & $\sqrt{ }$ \\
\hline & Human-human & .222 & .054 & .246 & $\begin{array}{l}.00 \\
0\end{array}$ & & & & $\sqrt{ }$ \\
\hline
\end{tabular}

$\sqrt{: \text { There is significant relationship }}$

$\mathrm{X}$ :. There is no relationship

Table 5 shows that Section 2 Urban Park fulfils both perceived benefits for the humannature interactions and human-human Apart from that, Section 8 Playing Field and Section 7 Local Park also accomplish the anticipated benefits of human-human interactions in the open spaces. This is due to the function of the public spaces whereby Section 8 functions as playing field. Hence, human interaction occurred highly in the area. Department of Town and Country Planning (2013), suggested that playfield should cater to three division of neighbourhood which functions as recreational activities for children, teenagers and adults. Department of Town and Country Planning (2013) suggested that local park should cater for local dwellers for recreational purposes, sport and social community. Hence, from the overall findings, it shows that the provision of open spaces in Section 7 effectively functions for the recreational purposes, sport and social community.

\subsection{Conclusion}

Human interaction is among the vital elements that should be incorporated in the open spaces planning. Although open spaces are commonly significance to the use of recreational activity and play, this study has shown that public areas are far more beneficial than recreational activities. Moreover, human-nature interaction always associated with green and open spaces but human-human nature interaction has always been overlooked. This study has shown that human-human interaction in open spaces also plays a significant value towards the urban dwellers.

Hence, the aspect of human interaction in open spaces planning is vital as the open spaces function to serve the human and natural habitat. Thus, it should be incorporated in the planning design as it helps to enhance the design of the open spaces. The professional groups such as urban planners, landscape architects should incorporate more aspects of human interaction and open spaces in their design and planning process. Moreover, citizen participation in the planning process should be included and improved to identify the residents' needs and towards the success of the open spaces provided.

Apart from that, human interaction framework and guidelines, especially in open spaces planning and design, should be implemented as there are no specific guidelines for open spaces interaction and preparation. It will then aid the designers in developing and designing open spaces for urban dwellers. Moreover, the instructions for open spaces planning should be revised as there are increasing and different trends differ from time to time. The relevance of open spaces planning and guidelines should incorporate human-human interactions 
needs, and human-nature interactions need to satisfy the requirements of urban dwellers.

In conclusion, the research conceives that there could be alternative views relating to the scope and process of an investigation conducted by the research. However, the positive feedback from the findings confirms that the research has achieved in making a significant contribution to the study on human interaction in open spaces. This research has made a substantial contribution to add to the body of knowledge in the realm of landscape architecture and urban planning. The research put forward and established a dynamic synergy between studies in human interaction in open spaces and indicators for a sustainable city. Within the scenario where research on social interaction is vastly lacking, this research sought to provide essential insights and develop new knowledge to the current practice in Malaysia.

This research has also significantly contributed to the local urban planners and decision makers by discovering the efficacy of human interactions in open spaces and its vitality towards city sustainability. To ensure its practicality, validity and reliability in the Malaysian context, the case studies selected were from several open chosen areas in Selangor, Malaysia.

This research has also identified the growing interest in human-nature interaction and human-human interaction in open spaces among the urban dwellers. The urban residents' attitudes gauged from the survey conducted provide a more in-depth understanding of the importance of the relationship between human-nature and human-human in open spaces. The findings of this research support that human needs in public areas are beneficial to the sustainability of a city. While most open spaces in Malaysia focused on the place making and natural wildlife, this research has increased knowledge on the positive values of open spaces and has highlighted the human-human interaction and human-nature interaction approaches that can be taken into open spaces design.

\section{Acknowledgement}

The authors would like to thank all officers of Universiti Teknologi MARA and Taylors University particularly whom in charge of this research publication. Special acknowledgements to the co-researchers in supporting the success of this research.

\section{References}

Abu-Ghazzeh, T.M., (1996). Reclaiming public space: the ecology of neighborhood open spaces in the town of AbuNuseir, Jordan. Landscape Urban Plan.36, 197-216.

Agency, C. I. D. (2012). Indicators for Sustainability: How Cities are Monitoring and Evaluating Their Success (84). Canada.

Ali, S. M., \& Nawawi, A. H. (2006). Factors That Influence User's Satisfaction on Urban Park: Comparison Between KLCC Park and Subang Recreational Park. Universiti Teknologi Mara. 
Chiesura, A. (2004). The role of urban parks for the sustainable city. Landscape and Urban Planning, 68(1), 129138. doi:10.1016/j.landurbplan.2003.08.003

Department of Town and Country Planning of Peninsular Malaysia (2013). Planning guidelines of open spaces and recreation areas. Ministry of Housing and Local Government.

Gobster, P.H., (2001). Visions of nature: conflict and compatibility in urban park restoration. Landscape Urban Plan. $56,35-51$.

Illia, F., Omar, D., \& Hanita, N. (2013). Human Interaction in Open Spaces, (December), 17-18.

Illia, F., Omar, D., \& Hanita, N. (2014). Theoretical Review on Sustainable City Indicators in Malaysia, 04.

Jim, C.Y., Chen, W.Y., (2006a). Recreation-amenity use and contingent valuation of urban greenspaces in Guangzhou. China. Landscape Urban Plan. 75, 81-96.

Jim, C.Y., Chen, W.Y., (2006b). Impacts of urban environmental elements on residential housing prices in Guangzhou (China). Landscape Urban Plan. 78, 422-434.

Mamaghani, N. K., Asadollahi, A. P., \& Mortezaei, S.-R. (2015). Designing for Improving Social Relationship with Interaction Design Approach. Procedia - Social and Behavioral Sciences, 201(February), 377-385.

https://doi.org/10.1016/j.sbspro.2015.08.190

Mansor, M., Said, I., \& Mohamad, I. (2010). Experintal Contacts with Green Infrastructure's Diversity and Well Being of Urban Community. Asian Journal of Environment-Behaviour Studies, 31-47

Marzukhi, M. A., Karim, H. A., \& Latfi, M. F. (2012). Evaluating the Shah Alam City Council Policy and Guidelines on the Hierarchy of Neighborhood Open Space. Procedia - Social and Behavioral Sciences, 36(June 2011), 456465. doi:10.1016/j.sbspro.2012.03.050

Marzukhi, M. A., Omar, D., Oliver, L. H. L., Hamir, M. S., \& Barghchi, M. (2011). Malaysian Urban Indicators Network: A Sustainable Development Initiative in Malaysia, 25(1), 77-84.

Matsuoka, R. H. (2008). High school landscapes and student performance, 121

Matsuoka, R. H., \& Kaplan, R. (2008). People needs in the urban landscape : Analysis of Landscape And Urban Planning contributions, 84, 7-19. doi:10.1016/j.landurbplan.2007.09.009

Omar, D., Illia, F., \& Hanita, N. (2015). Human Interaction in Open Spaces, 01, 1-9.

Philips, L.E., (1996). Parks: design and management,United States of America: McGrawHill.

Saleh, M.A.E., (1999). Reviving traditional design in modern Saudi Arabia for social cohesion and crime prevention purposes. Landscape Urban Plan. 44, 43-62.

Sas-Bojarska, A., \& Rembeza, M. (2016). Planning the City Against Barriers. Enhancing the Role of Public Spaces. Procedia Engineering, 161, 1556-1562. https://doi.org/10.1016/j.proeng.2016.08.626

Sekaran, U. (2013). Research methods for business. Research methods for business (Vol. 65). https://doi.org/10.1017/CBO9781107415324.004

Stewart,W.P., Liebert, D., Larkin, K.W., (2004). Community identities as visions for landscape change. Landscape Urban Plan. 69, 315-334. 
Ibrahim, F.I., et.al. / Asian Journal of Behavioural Studies (AjBeS), 4(16) May / Aug 2019 (pp.18-32)

Wu, J. (2014). Public open-space conservation under a budget constraint. Journal of Public Economics, 111, 96101. doi:10.1016/j.jpubeco.2013.12.008

Xu, L., You, H., Li, D., \& Yu, K. (2016). Urban green spaces, their spatial pattern, and ecosystem service value: The case of Beijing. Habitat International, 56, 84-95. https://doi.org/10.1016/j.habitatint.2016.04.00

Yung, E. H. K., Conejos, S., \& Chan, E. H. W. (2016a). Public open spaces planning for the elderly: The case of dense urban renewal districts in Hong Kong. Land Use Policy, 59, 1-11.

https://doi.org/10.1016/j.landusepol.2016.08.022 